\title{
Case study of cutting slope with progressive failure due to continuous excavation
}

\author{
Q. Li ${ }^{\text {i) }}$, Y. M. Wang ${ }^{\text {ii) }}$ and K. B. Zhang ${ }^{\text {iii) }}$
}

i) Ph.D Student, School of Civil Engineering and Transportation, South China University of Technology, Guangzhou, 510640, China. ii) Professor, School of Civil Engineering and Transportation, South China University of Technology, Guangzhou, 510640, China. iii) Ph.D Student, School of Civil Engineering and Transportation, South China University of Technology, Guangzhou, 510640, China.

\begin{abstract}
This paper reports a case study of progressive failure on a high cut slope due to continuous excavation. The characteristics of each stage failure induced by excavation are analyzed through geological investigation and field monitoring. The slope safety situation was monitored and analyzed. The monitoring results provide the important guidance for slope dynamic design and construction. It is important that the reinforcement of pre-stressed anchoring cables for the slope should be carried out after the slope excavation accomplished as soon as possible. Slope construction monitoring plays an important role in ensuring high slope safety. The results revealed that the slope instability was triggered by the continuous excavation of the slope, and the failure mode of slope is progressive sliding.
\end{abstract}

Keywords: instability, continuous excavation, high cut slope, failure mode

\section{INTRODUCTION}

In recent years, with the extension of expressway to mountainous areas, a large number of high cutting slopes have appeared in China. High slopes are often affected by terrain conditions and human activities, and are often prone to landslide disasters (Wang et al. 2013, Xu et al. 2012, Zhang et al. 2012, Zhang et al. 2014). The high cutting slope of highway usually has a long construction period for excavation and reinforcement, but in this long period, it often faces the interference of continuous rainfall, snow weather and other environmental factors. If there is no good organization and construction scheduling, the excavation slope does not have timely reinforcement measures, which is likely to cause the slope stability to gradually reduce and makes the deformation of rock and soil mass accumulates, and finally sliding failure occurs.

Through the study on the geomechanical model test of soft rock slope, under the condition of layered excavation without retaining structure, unloading stress will cause large deformation of the slope and eventually lead to slope instability (Xiao et al. 2007). Guo et al. (2013) based on the strength reduction method and limit equilibrium method calculation, the safety factor of slope gradually reduces with excavation, and adopting the construction form of excavation with supporting meantime is very necessary. During the excavation process of soft rock, the horizontal displacement and the vertical displacement showed gradually increasing trend, the vertical displacement of different feature points was generally bigger than the horizontal displacement (He et al.
2013). Therefore, it is necessary to adopt reasonable construction methods and optimize the design of the strengthening and enhancing engineering (Nie and Zhou 2011).

This paper presents a siltstone high slope which is instability during excavation and construction of $\mathrm{K} 443+260 \sim \mathrm{K} 443+585$ in Renbo Expressway, Guangdong Province, China. The field monitoring of surface displacement, deep displacement and anchor stress was carried out. The process of deformation non convergence development and gradual traction failure under repeated disorder excavation is analyzed. The monitoring and analysis results can provide the basis for dynamic design and information construction of slope. To ensure the safety and stability during slope excavation construction, and provide reference for similar projects.

\section{PROJECT OVERVIEW}

\subsection{Engineering geological properties}

According to the geological survey report, the main rock and soil layers of the studied slope are residual silty clay (Table. 1), fully weathered to strongly weathered siltstone (soil; $\mathrm{D}_{3}{ }^{\mathrm{m}}$ ), strongly weathered siltstone (fragmented; $\mathrm{D}_{3}{ }^{\mathrm{m}}$ ), moderately weathered siltstone (fragmented; $\mathrm{D}_{3}{ }^{\mathrm{m}}$ ), and slightly weathered siltstone (thick layer; $\mathrm{D}_{3}{ }^{\mathrm{m}}$ ). The main inclination of the strata is $110^{\circ} \sim 120^{\circ}$. The slope excavation surface inclines to $122^{\circ}$, and the relationship between the rock strata and the slope surface is a small-angle bedding slope. 
Table 1. Property and distribution of main soil layers of the slope.

\begin{tabular}{|c|c|c|c|c|c|c|}
\hline \multirow[t]{2}{*}{ Name of stratum } & \multirow[t]{2}{*}{ Number } & \multirow[t]{2}{*}{ Characteristics } & \multicolumn{3}{|c|}{ Physical and mechanical parameters } & \multirow[t]{2}{*}{ Distribution } \\
\hline & & & $\begin{array}{l}\text { Unit weight } \\
(\mathrm{kN} / \mathrm{m} 3)\end{array}$ & $\begin{array}{l}\text { Cohesion } \\
(\mathrm{kPa})\end{array}$ & $\begin{array}{l}\text { Internal friction } \\
\text { angle }\left(^{\circ}\right)\end{array}$ & \\
\hline Silty clay & $\mathrm{Q}^{\mathrm{dl}}$ & $\begin{array}{l}\text { Hard plastic, including } \\
\text { weathered gravel }\end{array}$ & $18 \sim 19$ & $26 \sim 29$ & $23 \sim 26$ & $\begin{array}{l}\text { Sporadic distribution with } \\
\text { a thickness of } 5.40 \mathrm{~m}\end{array}$ \\
\hline $\begin{array}{l}\text { Fully weathered } \\
\text { siltstone }\end{array}$ & $\mathrm{D}_{3} \mathrm{~m}$ & $\begin{array}{l}\text { Semi-rock and semi-soil, } \\
\text { very soft }\end{array}$ & $21 \sim 22$ & $26 \sim 33$ & $28 \sim 30$ & $\begin{array}{l}\text { Full site distribution, } \\
\text { thickness } 10.00 \sim 28.20 \mathrm{~m}\end{array}$ \\
\hline $\begin{array}{l}\text { Strongly weathered } \\
\text { siltstone }\end{array}$ & $\mathrm{D}_{3}{ }^{\mathrm{m}}$ & $\begin{array}{l}\text { The fracture is well } \\
\text { developed and the rock } \\
\text { is relatively soft. }\end{array}$ & $21 \sim 22$ & $30 \sim 33$ & $30 \sim 32$ & $\begin{array}{l}\text { Local } \\
\text { thickness } 1.50 \sim 6.50 \mathrm{~m}\end{array}$ \\
\hline $\begin{array}{l}\text { Moderately } \\
\text { weathered siltstone }\end{array}$ & $\mathrm{D}_{3}{ }^{\mathrm{m}}$ & $\begin{array}{l}\text { The rock is relatively } \\
\text { broken and hard. }\end{array}$ & $22 \sim 23$ & $35 \sim 40$ & $32 \sim 35$ & $\begin{array}{ll}\text { Local distribution, } \\
\text { thickness } 5.90 \sim 11.50 \mathrm{~m}\end{array}$ \\
\hline $\begin{array}{l}\text { Slightly weathered } \\
\text { siltstone }\end{array}$ & $\mathrm{D}_{3}{ }^{\mathrm{m}}$ & $\begin{array}{l}\text { Layered structure, hard } \\
\text { rock }\end{array}$ & $22 \sim 23$ & $35 \sim 40$ & $32 \sim 35$ & $\begin{array}{l}\text { Full site distribution, with } \\
\text { the maximum thickness of } \\
11.50 \mathrm{~m}\end{array}$ \\
\hline
\end{tabular}

2.2 Initial reinforcement design scheme for the slope

The original design of the slope is a 6-grade excavated slope (Fig. 1) with the maximum height up to $62 \mathrm{~m}$. The slope ratios of both the 1 st and the 2 nd grade slopes are 1:0.75, the slope ratios of the 3rd to 5th grade slopes are $1: 1$, and the slope ratio of the 6th grade slope is $1: 1.25$. The heights of the 1 st to 5 th grade slopes are all $10 \mathrm{~m}$, and the height of the 6th grade slope is $12 \mathrm{~m}$. Benches with a width of $2 \mathrm{~m}$ are set between any two adjacent grade slopes. The 1 st grade slope is strengthened with four rows of anchor lattice beams, and the length of the anchorage segment is $8 \mathrm{~m}$. The 2nd to 4th grade slopes are strengthened with three rows of anchor cable frame beams, and the length of the anchor cable is $20 \mathrm{~m}, 22 \mathrm{~m}$ and $24 \mathrm{~m}$, the length of the anchorage segment is $10 \mathrm{~m}$, and the design pre-stress is $400 \mathrm{kN}$.

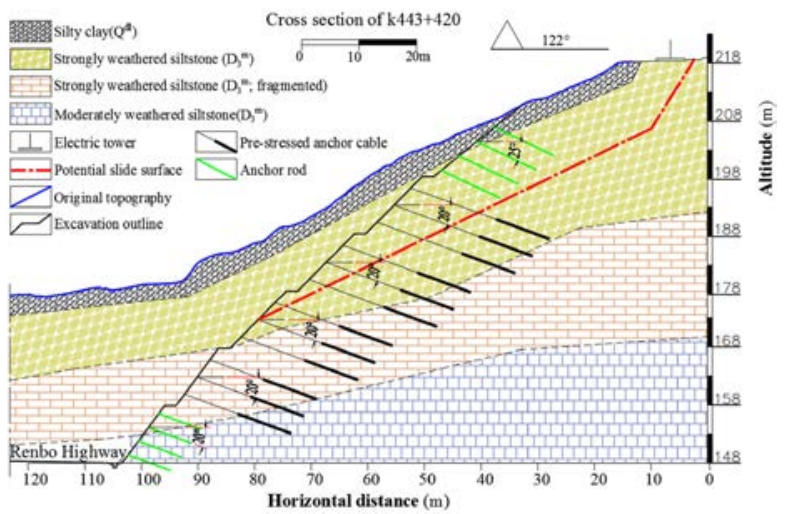

Fig. 1. The reinforced profile of initial design scheme (cross section of $\mathrm{k} 443+420$ ).

\section{EXCAVATION AND DEFORMATION PROCESS}

The slope is excavated from top to bottom, and the construction process can be roughly divided into four stages. The main construction contents and slope stability conditions of each stage are summarized in Table 2.

The excavation of the slope began in September 2016.
To speed up the progress of the construction, the upper 3 grade slopes were excavated continuously without any reinforcement measures. Affected by the excavation, the bare rock and soil mass on the slope underwent unloading and relaxation deformation, which resulted in shallow collapse on the fourth and fifth grade slopes on November 24, 2016.

Then, in the third stage, from January to April 2017. Affected by the seasonal rainfall in the region, the actual construction time is limited, and the anchor cable is completed grouting and tensioning in such a tight construction period, lead to insufficient anchoring force of most cables. The slope showed accelerated sliding and deterioration of stability, producing local uplift on the leading edge, and the original collapse area was triggered and moved.

Finally, in the fourth stage, from May to August 2017. Some areas have been excavated to the slope toe, and the disturbed areas have not been reinforced in time. Cracks appeared on the natural slope near the electric tower at the top of the slope.

\section{MONITORING INSTRUMENTATION}

\subsection{Monitoring scheme and layout}

The instruments in the monitoring system include four deep boreholes, four anchor cable dynamometer and eight surface displacement monitoring points. Fig. 2 shows the detailed arrangement of the monitoring instruments in the study area.

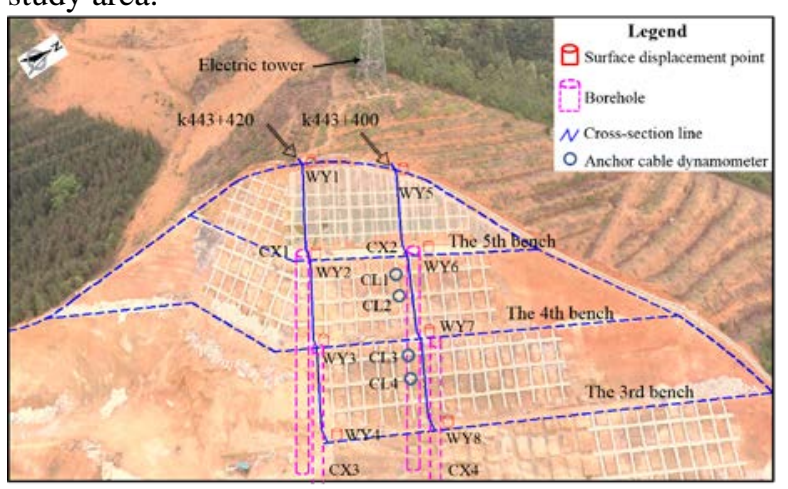

Fig. 2. Layout of the site monitoring points on the slope 
Table 2. Slope construction process at section K443+260 K443+585

\begin{tabular}{l|l|l|l}
\hline $\begin{array}{l}\text { Construction } \\
\text { stage }\end{array}$ & Time interval & Construction content & Deformation and instability process of the slope \\
\hline I & $2016-09-2016-10$ & $\begin{array}{l}\text { The 6th grade slope was excavated } \\
\text { without reinforcement }\end{array}$ & Stable state \\
\hline II & $2016-11-2016-12$ & $\begin{array}{l}\text { The excavation of the 4th to 5th grade } \\
\text { slopes were completed without any } \\
\text { reinforcement measures }\end{array}$ & $\begin{array}{l}\text { Shallow collapse on the fourth and fifth grade } \\
\text { slopes on November 24, 2016. The collapse area } \\
\text { was approximately 20 m in length and } 8 \mathrm{~m} \text { in } \\
\text { height, and it was a whole block of loose collapse }\end{array}$ \\
\hline III & $2017-01-2017-04$ & $\begin{array}{l}\text { The 4th to 5th grade slopes were } \\
\text { reinforced with anchor cable and then } \\
\text { excavated the 3rd grade slope }\end{array}$ & $\begin{array}{l}\text { Local uplift on the slope leading edge, and the } \\
\text { original collapse area was triggered and moved }\end{array}$ \\
\hline IV & $\begin{array}{l}\text { The 3rd grade slope was reinforced with } \\
\text { anchor cable, and then the mountain } \\
\text { partially excavated to the 1st grade slope. }\end{array}$ & $\begin{array}{l}\text { Cracks appeared on the natural slope near the } \\
\text { electric tower at the top of the slope. The } \\
\text { maximum width and depth of the cracks were 7 } \\
\text { cm and 70 cm, respectively }\end{array}$ \\
\hline
\end{tabular}

\subsection{Results and analysis}

Stage II of slope construction (2016-11-2016-12): In the second stage, only the surface displacement is arranged. Due to continuous excavation and no reinforcement measures taken in time, the surface displacement rate of the slope shows an accelerated upward trend (stage II in Fig. 3). Under the influence of continuous excavation disturbance, the maximum surface displacement at the end of this stage is $29 \mathrm{~mm}$.

Stage III of slope construction (2017-01-2017-04): In this stage, the surface displacement, depth displacement and the anchor force are monitored regularly. For the surface displacement data (Fig.3), the change of displacement shows an increasing form of non-convergence. The maximum displacement point is located at the 5th bench, and the maximum displacement is $118 \mathrm{~mm}$. Similarly, the tensile force of the anchor cable increases abnormally (Fig. 4), which is contrary to the conclusion that the stress of the anchor cable should be lost after tensioning, this indicates that the anchor cable is subjected to a large sliding force generated by the sliding body at this stage, and anchor cable plays a positive role in antisliding. The deep displacement monitoring results can be clearly seen (Fig. 5 and Fig. 6), during this period, the slope entered the stage of accelerated deformation. When CX1 and CX2 were monitored on March 20 and April 2, 2017, it was found that only part of the monitoring instruments could be inserted, so it was judged that the displacement of the slope was too large and both boreholes were cut. The intersected point of CX1 was at $11 \mathrm{~m}$ and that of CX2 was at $19 \mathrm{~m}$. The maximum cumulative displacements of CX1 and CX2 before shearing were $36.64 \mathrm{~mm}$ and $70.38 \mathrm{~mm}$, respectively. From February 28, 2017, to March 28, 2017, the average displacement rate of the CX1 borehole at a depth of $11 \mathrm{~m}$ was $1.72 \mathrm{~mm} / \mathrm{d}$ and that of the CX2 borehole at a depth of $19 \mathrm{~m}$ was $2.1 \mathrm{~mm} / \mathrm{d}$. Both sets of data showed that the slope had a deep landslide with an obvious sliding surface.

Slope construction stage IV (2017-05-2017-08): After both boreholes of CX1 and CX2 were broken, two new boreholes of CX3 and CX4 were added to the 4th bench of the original section. According to three groups of data, the overall displacement of the slope is not controlled, and each group of data increases significantly, with the maximum anchor force of 581 $\mathrm{kN}$ and the maximum surface displacement of $141 \mathrm{~mm}$.

Based on the above monitoring data and field investigation, the deformation and failure of the slope mainly experienced four stages: local collapse of the slope surface, formation of cracks at the foot of the slope, leading edge extrusion and trailing edge tension cracks. The failure mode of slope is progressive sliding.

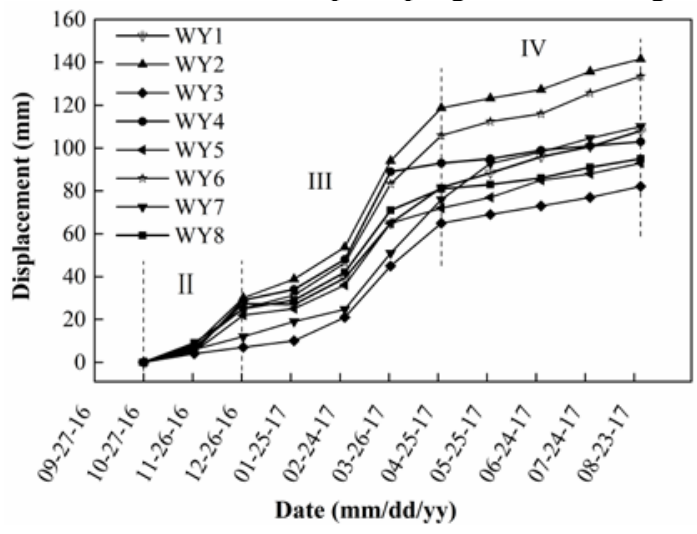

Fig. 3. Change of slope surface displacement with time.

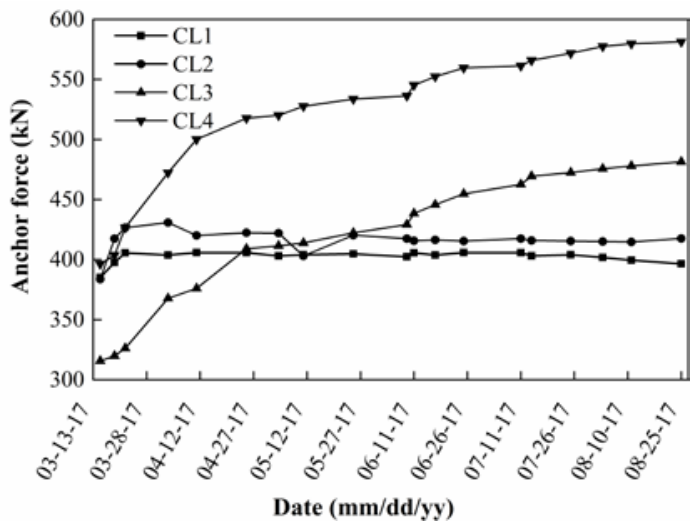

Fig. 4. Change of anchor force with time at the section of K443+400. 


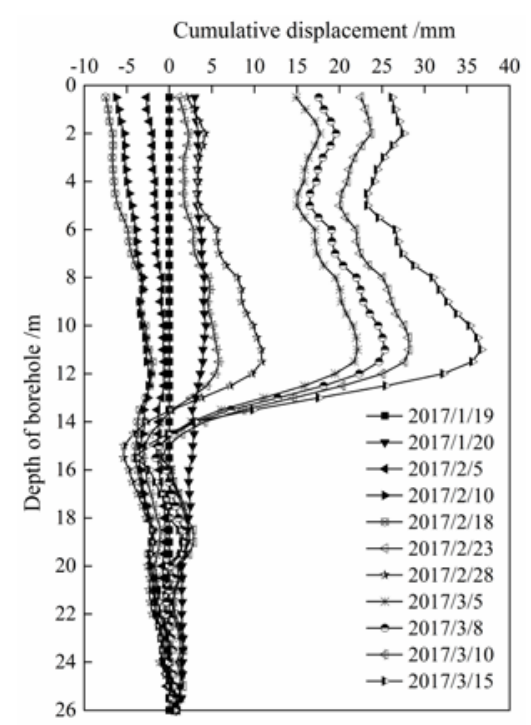

(a)

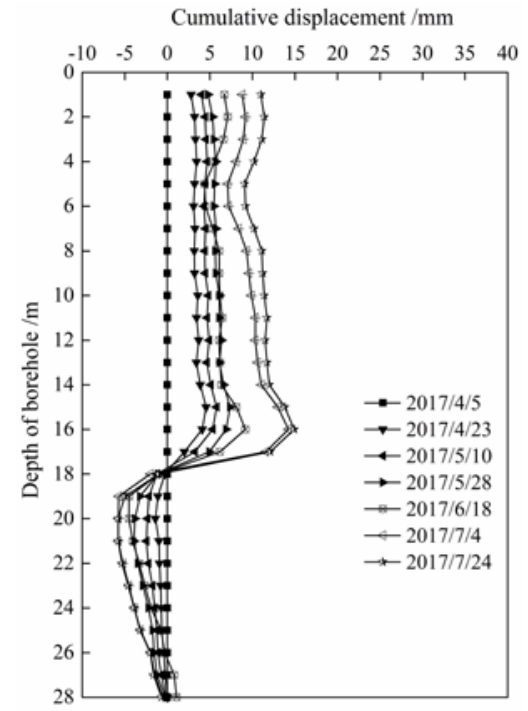

(b)

Fig. 5. Cumulative deep displacement curves at the section of K443+420: a displacement at CX1 and b displacement at CX3.

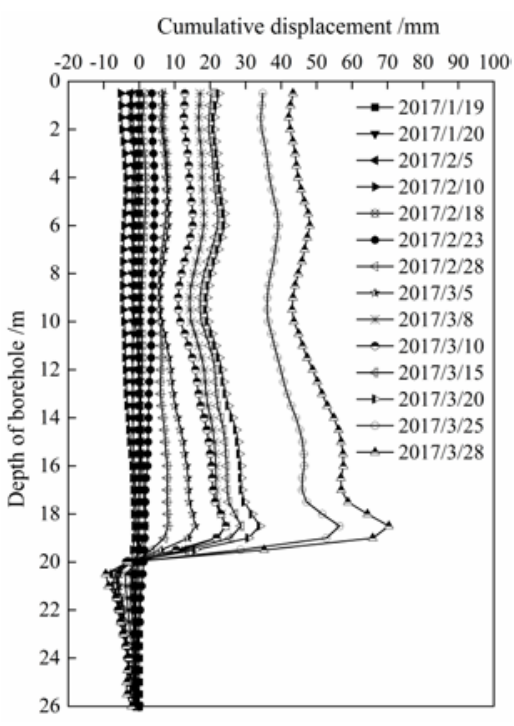

(a)

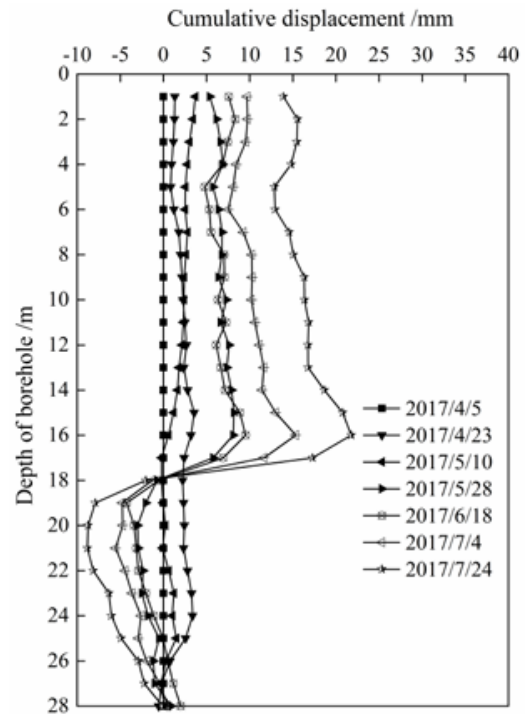

(b)

Fig. 6. Cumulative deep displacement curves at the section of K443+400: a displacement at CX2 and b displacement at CX4.

\section{CONCLUSIONS}

The progressive failure on a high cut slope are analyzed based on the field investigations and monitoring after each stage. The following conclusions can be drawn:

(1) Continuous excavation is one of the main causes of slope deformation and instability, so it is necessary to reinforce the slope in time after excavation, and then carry out the next stage of excavation. At the same time, in the whole construction process, time should be reasonably organized to avoid construction in rainy season as much as possible.

(2) Slope monitoring can accurately reflect the deformation trend and stress state of the slope, which is a very necessary means to ensure the construction safety of the slope, and provides reliable guidance for the dynamic design and construction of the expressway slope.

(3) In the construction process of high cutting slope, the corresponding dynamic flexible design shall be carried out in time according to the stratum lithology, monitoring data and artificial patrol information revealed after excavation. The original design scheme shall be adjusted in time and effectively, the design scheme shall be optimized, the slope diseases in the construction process shall be effectively controlled, and the orderly and reasonable information construction shall be realized. 
(4) Carry out scientific planning of slope construction process, avoid adverse construction seasons such as rainy season, selecting professional teams with strong technical level to carry out construction, strictly control the construction quality of the project, and provide quality assurance for the long-term safety of the slope project.

\section{ACKNOWLEDGEMENTS}

This research is financially supported by the National Key R\&D Program of China (2016YFC0802500) and the Traffic Science and Technology Project of Guangdong Province (2014-02-04).

\section{REFERENCES}

1) Guo, F., Gu, W., Tang, J. and Murong, M. (2013): Research on deformation stability of soft rock slope under excavation based on flac3d. Applied Mechanics and Materials 275-277: 290-294.

2) He, Z., Wu, W. and Zeng, L. (2013): Excavation response of soft rock high slope considering strain softening feature. 536-539. doi: 10.1109/icmtma.2013.133.

3) Nie, L. and Zhou, D. (2011): Excavation deformation analysis of deep-cutting high rock slope. Advanced Materials Research 368-373: 219-224. 4) Wang, J., Liang, Y., Zhang, H., Wu, Y. and Lin, X. (2013): A loess landslide induced by excavation and rainfall. Landslides 11: 141-152. doi: 10.1007/s10346-013-0418-0.

5) Xiao, K., Zhou, D. and Hai-Bo, L. (2007): Physical modeling of deformation properties for soft rock slope under excavation. Rock \& Soil Mechanics 28: 111-110. (in Chinese)

6) Xu, L., Dai, F., Chen, J., Iqbal, J. and Qu, Y. (2012): Analysis of a progressive slope failure in the xiangjiaba reservoir area, southwest china. Landslides 11: 55-66. doi: 10.1007/s10346-012-0373-1.

7) Zhang, F., Liu, G., Chen, W., Liang, S., Chen, R. and Han, W. (2012): Human-induced landslide on a high cut slope: A case of repeated failures due to multi-excavation. Journal of Rock Mechanics and Geotechnical Engineering 4: 367-374. doi: 10.3724/sp.j.1235.2012.00367.

8) Zhang, M., Nie, L., Xu, Y. and Dai, S. (2014): A thrust load-caused landslide triggered by excavation of the slope toe: A case study of the chaancun landslide in dalian city, china. Arabian Journal of Geosciences 8: 6555-6565. doi: 10.1007/s12517-014-1710-6. 